\title{
Microbial communities in Cerrado soils under native vegetation subjected to prescribed fire and under pasture
}

\author{
Laura Tillmann Viana(1), Mercedes Maria da Cunha Bustamante ${ }^{(2)}$, Marirosa Molina(3), \\ Alexandre de Siqueira Pinto(2), Keith Kisselle ${ }^{(4)}$, Richard Zepp ${ }^{(3)}$ and Roger A. Burke ${ }^{(3)}$
}

\begin{abstract}
(1)Agência Nacional de Águas, Setor Policial Sul, Área 5, Bloco L, CEP 70610-200, Brasília, DF, Brazil. E-mail: laura.viana@ana.gov.br (2)Universidade de Brasília, Departamento de Ecologia, Campus Universitário Darcy Ribeiro, ICC Sul, CEP 70919-970 Brasília, DF, Brazil. E-mail: mercedes@unb.br, alexandresp@unb.br (3)United States Environmental Protection Agency, 960 College Station Road, Athens, Georgia 30605-2700 USA. E-mail: molina.marirosa@epamail.epa.gov, zepp.richard@epamail.epa.gov, burke.roger@epamail.epa.gov ${ }^{(4)}$ Austin College, Department of Biology and Environmental Studies, $900 \mathrm{~N}$ Grand Avenue, suite 61610, Sherman, TX 75090 USA. E-mail: kkisselle@austincollege.edu
\end{abstract}

\begin{abstract}
The objective of this work was to evaluate the effects of fire regimes and vegetation cover on the structure and dynamics of soil microbial communities, through phospholipid fatty acid (PLFA) analysis. Comparisons were made between native areas with different woody covers ("cerrado stricto sensu" and "campo sujo"), under different fire regimes, and a 20-year-old active palisadegrass pasture in the Central Plateau of Brazil. Microbial biomass was higher in the native plots than in the pasture, and the highest monthly values were observed during the rainy season in the native plots. No significant differences were observed between fire regimes or between communities from the two native vegetation types. However, the principal component (PC) analysis separated the microbial communities by vegetation cover (native $\mathrm{x}$ pasture) and season (wet $\mathrm{x}$ dry), accounting for $45.8 \%$ (PC1 and PC3) and 25.6\% (PC2 and PC3), respectively, of the total PLFA variability. Changes in land cover and seasonal rainfall in Cerrado ecosystems have significant effects on the total density of soil microorganisms and on the abundance of microbial groups, especially Gram-negative and Gram-positive bacteria.
\end{abstract}

Index terms: land use, microbial diversity, PLFA, savannas, seasonality.

\section{Comunidades microbianas de solos de Cerrado sob vegetação nativa sujeita a queimadas prescritas e sob pastagem}

\begin{abstract}
Resumo - O objetivo deste trabalho foi avaliar os efeitos de regimes de queima e cobertura vegetal sobre a dinâmica e a estrutura de comunidades microbianas do solo, por meio da análise de perfis de ácidos graxos de fosfolipídeos (PLFA). Compararam-se áreas nativas com diferentes coberturas vegetais (cerrado stricto sensu e campo sujo), sob diferentes regimes de queima e uma pastagem de capim-braquiária de 20 anos, no Planalto Central do Brasil. A biomassa microbiana foi maior nas parcelas com vegetação nativa que na pastagem, e os maiores valores mensais foram observados durante a estação chuvosa nas parcelas nativas. Apesar de não terem sido observadas diferenças significativas como consequência das queimadas ou entre as vegetações nativas, a análise de componentes principais separou as comunidades microbianas pela cobertura vegetal (nativa x pastagem) e pela sazonalidade (chuvosa x seca), tendo explicado 45,8 e 25,6\%, respectivamente, da variabilidade de PLFA total. Mudanças na cobertura do solo e a sazonalidade na precipitação têm efeito significativo sobre a densidade total e a abundância de grupos de microrganismos do solo no Cerrado, especialmente bactérias Gram-negativas e Gram-positivas
\end{abstract}

Termos para indexação: uso da terra, diversidade microbiana, PLFA, savanas, sazonalidade.

\section{Introduction}

Savannas of Central Plateau of Brazil, locally known as Cerrado, comprise the second largest biome of South America with an area of approximately two million square kilometers. The Cerrado is characterized by high plant diversity and different vegetation types forming a density gradient of woody species.

The Cerrado is one of the 34 biodiversity hotspots in the world, i.e., areas with high biodiversity and accelerated loss of habitats (Mittermeier et al., 2005). Rapid conversion of native Cerrado areas to agriculture has been occurring since 1960 with the establishment of the Brazilian Federal District and the construction of Brasília. By 2002, approximately $39.5 \%$ of the Cerrado was already converted primarily into pastures (26.5\%), and cropland (10.5\%), (Sano et al., 2008).

Fire is commonly used as a management practice during the dry season to promote fresh grass re-growth in pastures, clearing of areas for cultivation and

Pesq. agropec. bras., Brasília, v.46, n.12, p.1665-1672, dez. 2011 
eliminating undesirable species. Burning can modify not only the soil chemical and physical properties (such as $\mathrm{pH}$, cation exchange capacity, moisture, and porosity), but also, depending on the frequency, the vegetation structure favoring the herbaceous layer (Miranda et al., 2002).

While different studies have demonstrated the impact of the conversion and fragmentation on the flora and fauna of the Cerrado (Durigan et al., 2007; Borges \& Marini, 2010), little is known about the impacts of these processes on the soil microbial communities. Changes in plant diversity due to land use impact ecosystem processes by modifying the composition and function of the heterotrophic soil microbial communities. A recent study confirmed the relationships between microbial community function and specific plant traits (Eisenhauer et al., 2010).

Soil microorganisms are responsible for critical environmental services by playing an important role as mediators of biogeochemical cycles. Central questions regarding microbial communities include the controls of the distribution and abundance of species and functional groups and how these communities change with time in response to their environment. Many different factors have been shown to affect soil microbial communities, including soil types (Bossio et al., 1998), vegetation cover and seasonality (Habekost et al., 2008), and natural and anthropogenic disturbances such as burning (Swallow et al., 2009). Land use changes and management have also been found to alter microbial community structure (Drenovsky et al., 2010).

Changes in the structure of microbial communities can be assessed using a variety of approaches at the genetic and phenotypic levels. At the genetic level, extraction of total microbial community DNA and subsequent analysis of DNA fragments provides detailed information about the structure of microbial community. However, the high level of resolution, provided by most DNA molecular approaches terminal restriction fragment length polymorphism, denaturing and temperature gradient gel electrophoreses -, is representative of the total genetic diversity of the community, - including dead, quiescent, and alive microorganisms. While early responses in a microbial community often occur at the more broad functional and taxonomic levels, the high level of genetic diversity in an undisturbed community, provided by the DNA molecular approaches, might mask early responses to environmental change in the active microbial community. Phospholipid fatty acid analysis provides a measurement of microbial communities diversity at the phenotypic level, allowing for the comparison of broad taxonomic groups such as fungi and bacteria in the same sample (Baath \& Anderson, 2003). Although it does not allow for differentiation of microorganisms at the species level, it provides a quantitative assessment of the various active groups within the microbial community. In addition, specific shifts in the ratios of certain individual compounds can be used as a measurement of stress in the community (Persson et al, 1989; Tunlid \& White, 1992; Heipieper et al., 1996). Microbial fatty acids are mainly composed of five types of lipids: saturated straight and branched chain, usually produced by Gram-positive bacteria (O'Leary \& Wilkinson, 1988); monounsaturated and cyclopropane, common in Gram-negative bacteria (Wilkinson, 1988); and polyunsaturated fatty acids, characteristic of eukaryotic organisms (Federle, 1986).

The objective of this work was to evaluate the effects of fire regimes and vegetation cover on the structure and dynamics of soil microbial communities, through phospholipid fatty acid (PLFA) analysis.

\section{Materials and Methods}

Two distinct Cerrado native vegetation physiognomies - "Cerrado stricto sensu" (ss) and "campo sujo" - and a Urochloa brizantha (Syn. Brachiaria brizantha) pasture were studied. The native vegetation plots are located at the Reserva Ecologica of the Instituto Brasileiro de Geografia e Estatística (IBGE) $\left(15^{\circ} 56^{\prime} \mathrm{S}, 4^{\circ} 51^{\prime} \mathrm{W}\right), 35 \mathrm{~km}$ south of Brasília, DF, Brazil. The $U$. brizantha pasture was established in 1982, in an experimental farm of Embrapa Cerrados $\left(15^{\circ} 39^{\prime} \mathrm{S}, 47^{\circ} 45^{\prime} \mathrm{W}\right)$. The distance between both sites is around $35 \mathrm{~km}$.

The regional climate is tropical and seasonal (Aw, Köeppen classification), with a dry season from April to September and a rainy season from October to March. Annual accumulated precipitation during the study period was $1,478 \mathrm{~mm}$ in the native vegetation areas and $1,190 \mathrm{~mm}$ in the pasture, according to the meteorological stations located at the Reserva Ecologica of IBGE and at Embrapa Cerrados, respectively. Approximately $90 \%$ of the annual precipitation falls during the rainy season. 
The soils of both sites are the same age and have been subjected to the same formation processes, as the native vegetation and the pasture occupied respectively the central part and the borders of the same geomorphological surface (plateau). Dominant soils in the region are acidic, with high aluminum levels and low cation exchange capacity. They are classified as Latossolos (Oxisols) by the Sistema Brasileiro de Classificação do Solo (Santos et al., 2006).

The Reserva Ecologica of IBGE is the only Cerrado site with a well-known history on fire regime. A description of the Fire Project can be found in Nardoto et al. (2006). The "Cerrado ss" is composed of 3 to $6-\mathrm{m}$-tall trees and shrubs forming a 20 to $50 \%$ canopy cover. The campo sujo physiognomy presents a lower degree of woody cover than the "Cerrado ss" and is composed mainly of grasses and sparse shrubs. Two plots of each native vegetation type were selected: one plot of each physiognomy was protected from fire since 1974, and the other plot was burned every two years at the end of the dry season (September) since 1992. "Cerrado ss" and "campo sujo" plots have an area of 10 ha and 4 ha, respectively. Soil is classified as a Latossolo Vermelho (Plinthic Haplustox) in the "Cerrado ss" and a Latossolo Vermelho-Amarelo (Typic Hapludox) in the "campo sujo" plots (Santos et al., 2006).

In the experimental farm of Embrapa Cerrados, the cerrado vegetation of the area was replaced in 1982 by a pasture, which was fertilized and divided into 1.0 ha plots for agricultural studies. One of the plots located at the border of a gently sloping (3-5\%) tableland at about 1,200 m altitude, was chosen for this work. After plowing and fertilization in 1992, the pasture was replaced by a corn plantation. Corn was cultivated for two years and, then, a new pasture of $U$. brizantha was established. Soil pits in the pasture area revealed the presence of charcoal particles which indicated historic fires, but after the conversion of original vegetation to pasture, the area was not burned. Soil is classified by Santos et al. (2006) as Latossolo Vermelho (Plinthic Haplustox).

Soil characteristics $(0-5 \mathrm{~cm}$ depth) of the studied plots are shown in Table 1. Soil bulk density in the native plots ranged from $0.64 \mathrm{~kg} \mathrm{dm}^{-3}$ (unburned "Cerrado ss") to $0.79 \mathrm{~kg} \mathrm{dm}^{-3}$ (burned "campo sujo"), while in the pasture this value was $0.86 \mathrm{~kg} \mathrm{dm}^{-3}$. The soil clay content ranged from 580 to $740 \mathrm{~g} \mathrm{~kg}^{-1}$ in the native plots and was $570 \mathrm{~g} \mathrm{~kg}^{-1}$ in the pasture. The soil $\mathrm{C} / \mathrm{N}$ ratio was lower in pasture plot (9.6) than in the native plots (22.2) due to higher total $\mathrm{N}$ concentration in the pasture. The soil $\mathrm{pH}$ value in the pasture was 5.3 and ranged from 4.4 to 5.0 in the native plots.

Soil samples ( $0-5 \mathrm{~cm}$ depth) for PLFA analysis were collected monthly from June 2000 to May 2001 from each native plot and the pasture. The fifth prescribed fire at burned plots occurred in September 2000. Considering the strong seasonality of rainfall in the region and limited capacity for sample processing, a more extensive sampling coverage in time (monthly samples along a year in five plots) was prioritized in relation to spatial sampling coverage. For PLFA analyses, 10 samples were collected in two transects 5 meters apart from each other and composited. At the laboratory, samples were sieved through a $2 \mathrm{~mm}$ mesh sieve, to remove coarse fragments and roots, and were then stored at $-19^{\circ} \mathrm{C}$ until lipid extraction and analysis. Additional soil samples $(0-5 \mathrm{~cm}$ depth) were also collected monthly to determine gravimetric water content.

Total lipids were extracted from soil samples using a modification of the Bligh-Dyer technique (Bligh \& Dyer, 1959). A one-phase solvent mixture $(95 \mathrm{~mL})$ of methanol, chloroform, and phosphate buffer (2:1:0.8 ratio) was added to $20 \mathrm{~g}$ of dry soil in a teflon bottle and rotated on a roller mill (US Stoneware, East

Table 1. Soil characteristics (0-5 cm depth) in unburned and burned native plots ("Cerrado ss" and "campo sujo") and in pasture plot ${ }^{(1)}$.

\begin{tabular}{|c|c|c|c|c|c|c|c|c|}
\hline \multirow[t]{2}{*}{ Plot } & Sand & Silt & Clay & $\mathrm{pH}$ & \multirow{2}{*}{$\begin{array}{l}\text { Bulk density } \\
--\left(\mathrm{kg} \mathrm{dm}^{-3}\right) \text {-- }\end{array}$} & Organic $\mathrm{C}$ & Total N & \multirow[t]{2}{*}{$\mathrm{C} / \mathrm{N}$} \\
\hline & -------- & $\left(\mathrm{g} \mathrm{kg}^{-1}\right.$ & --------- & & & \multicolumn{2}{|c|}{--------- $\left(\mathrm{g} \mathrm{kg}^{-1}\right)$--------- } & \\
\hline Unburned "Cerrado ss" & 150 & 110 & 740 & 4.4 & 0.64 & 36.0 & 1.6 & 21.8 \\
\hline Unburned "campo sujo" & 180 & 90 & 730 & 4.7 & 0.73 & 26.1 & - & - \\
\hline Burned "Cerrado ss" & 210 & 130 & 660 & 4.6 & 0.67 & 30.0 & 1.5 & 22.2 \\
\hline Burned "campo sujo" & 300 & 120 & 580 & 5.0 & 0.79 & 24.1 & - & - \\
\hline Pasture & 320 & 110 & 570 & 5.3 & 0.86 & 24.1 & 2.5 & 9.6 \\
\hline
\end{tabular}

(1)Source: Nardoto \& Bustamante (2003) for unburned and burned cerrado; Kato (2001) for unburned and burned campo sujo; Varella et al. (2004) for pasture. 
Palestine, OH, USA) for two hours. The solvent mixture was decanted, extra volumes of chloroform and phosphate buffer were added, and the mixture was allowed to separate overnight into two phases. Lipids collected in the organic phase were fractionated with an activated silica gel column (BondElut, Varian, CA, USA) into neutral lipids, glycolipids and phospholipids with volumes of chloroform, acetone and methanol, respectively. Phospholipids were methylated using a mild alkaline methanolysis (White et al., 1979) to form fatty acid methyl esters (FAMEs). FAMEs were purified using $\mathrm{NH}_{2}$ aminopropyl columns (BondElut, Varian, CA, USA) (Zelles \& Bai, 1994).

Lipid samples were analyzed using a Hewlett Packard (HP) 6890 Series gas chromatograph (GC) (Hewlett Packard, Palo Alto, CA, USA) equipped with a flame ionization detector (FID) and a 50-m DB-5 capillary column; film thickness, $0.33 \mu \mathrm{m}$; internal diameter, $0.2 \mathrm{~mm}-$, ( $\mathrm{J}$ and $\mathrm{W}$ Scientific, Folsom, CA, USA). The oven temperature was programmed to hold at $70^{\circ} \mathrm{C}$ for $2 \mathrm{~min}$, ramp from 70 to $160^{\circ} \mathrm{C}$ at $40^{\circ} \mathrm{C} \mathrm{min}^{-1}$, then ramp from $160^{\circ} \mathrm{C}$ to $280^{\circ} \mathrm{C}$ at $5^{\circ} \mathrm{C} \mathrm{min}{ }^{-1}$, with a final isothermal period of $20 \mathrm{~min}$. Individual compounds were quantified by FID response related to an internal standard (20:0 ethyl ester) added prior to $\mathrm{GC}$ analysis. Identification of individual compounds was based on relative retention times, compared to a prepared standard mixture (Sigma, St. Louis, MO, USA; and Matreya, Pleasant Gap, PA, USA) run with each batch of samples. Mass spectrometry was used to verify compound identification and to identify FAMEs not present in the standard mixture. The same temperature program and a similar 30-m DB-5 column; film thickness, $0.25 \mu \mathrm{m}$; internal diameter, $0.25 \mathrm{~mm}-$, were used in an HP 5890 Series II GC interfaced to a HP 5972 mass selective detector (Hewlett Packard, Palo Alto, CA, USA). The interface was kept at $280^{\circ} \mathrm{C}$ and the electron energy was $70 \mathrm{eV}$. Helium was used as carrier gas in both instruments.

Normality and homoscedasticity of data were tested using Kolmogorov-Smirnov and Levene tests, respectively. Soil moisture was analyzed using one way ANOVA with two factors (plot and season). Multiple comparisons were made using the Bonferroni test. Pearson correlation was used to evaluate the relationship between PLFA - in mole fraction (mol\%) - and soil moisture. To evaluate the effect of pasture treatment on the soil microbial community, means (mol\%) for pasture x unburned "campo sujo" and "Cerrado ss" were tested by ANOVA. PLFA profiles were compared by principal component analysis (PCA) using the mol\% of the most frequent PLFAs. Data were transformed to a normal distribution by using $\ln$ and $\mathrm{x}^{2}$ when necessary. ANOVA and Tukey tests at $5 \%$ probability were applied to the scores of the three first principal components to test significant differences between profiles due to vegetation cover, seasonality and burning effects. The SPSS program 17 for Windows was used.

\section{Results and Discussion}

Considering all the plots, the soil moisture was higher in the wet season $(F=20.315 ; D F=1 ; p<0.001)$. Soil moisture differed significantly among plots $(\mathrm{F}=11.591 ; \mathrm{DF}=4, \mathrm{p}<0.001)$ with lower values in the pasture than in the other plots $(p<0.003)$, except for the burned "campo sujo". Differences between unburned and burned plots were observed only in "campo sujo" plots $(\mathrm{p}=0.023)$ (Figure 1). The lower soil moisture

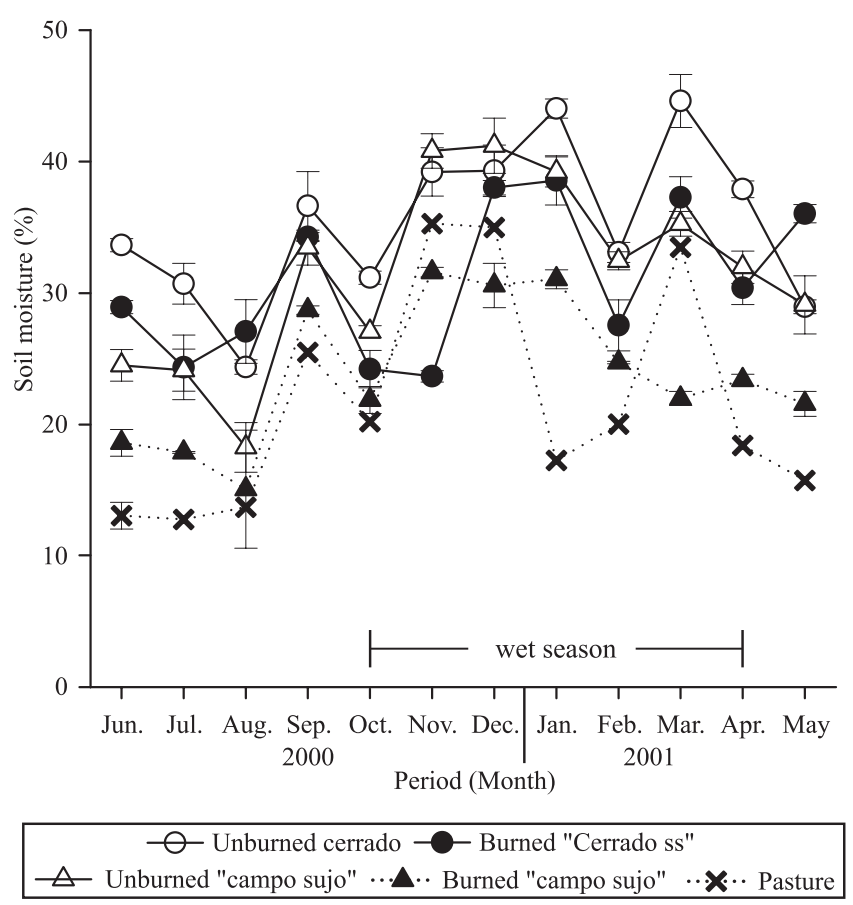

Figure 1. Seasonal patterns of soil moisture $(0-5 \mathrm{~cm}$ depth) in unburned and burned native plots ("Cerrado ss" and "campo sujo") and in pasture plot. Significant differences between means at $5 \%$ probability for the study period are indicated by lines with different styles (solid or dotted). Bars represent the standard error of the mean. 
values were observed in the burned "campo sujo" and pasture plots probably as a result from a combination of factors such as spatial variability in rainfall, differences in vegetation structure and functioning, soil bulk density, texture, and organic carbon content (Varella et al., 2004) (Table 1). In cerrado areas, frequent fires reduced the density of woody species (Moreira, 2000) influencing soil moisture content. The burned "campo sujo" has a more drastic reduction of the woody layer in relation to the burned cerrado ss. Small trees and shrubs, typical of "campo sujo" plots, are more sensitive to burning than are larger trees because susceptibility to fire depends on individual height and diameter of the individual (Miranda et al., 2002).

The mean total PLFA content was significantly different between the unburned native plots ("Cerrado ss" and "campo sujo") and the pasture plot (Table 2). The burned plots ("Cerrado ss" and "campo sujo") contained an intermediate PLFA concentration that was not significantly different from the other two

Table 2. Effects of seasonality on total phospholipid fatty acid $\left(\mu \mathrm{g} \mathrm{g}^{-1}\right)$ analysis of soil $(0-5 \mathrm{~cm}$ depth) in unburned and burned native plots ("Cerrado ss" and "campo sujo") and in pasture plot $^{(1)}$.

\begin{tabular}{lcll}
\hline Cerrado plot & Seasons combined & Wet season & Dry season \\
\hline Unburned & $25.6 \pm 11.1 \mathrm{a}$ & $25.4 \pm 10.9 \mathrm{a}$ & $26.5 \pm 12.8 \mathrm{a}$ \\
Burned & $24.4 \pm 9.0 \mathrm{ab}$ & $22.8 \pm 8.9 \mathrm{a}$ & $29.0 \pm 8.4 \mathrm{a}$ \\
Pasture & $16.8 \pm 8.5 \mathrm{~b}$ & $13.9 \pm 5.9 \mathrm{~b}$ & $23.4 \pm 10.4 \mathrm{a}$ \\
\hline
\end{tabular}

(1)Means \pm standard deviation followed by equal letters, in columns, do not differ by Tukey test, at $5 \%$ probability. groups. Considering the mean total PLFA content in the wet season, unburned and burned plots had similar values despite contrasting soil properties, especially texture (Table 1). In the wet season, soil humidity is high enough to limit a potential effect of soil physical characteristics, while the significantly higher values in native plots compared to pasture (13.9 $\mu$ g PLFA per $g$ of dry soil) suggested that the microbial biomass can be controlled by vegetation cover (density and diversity of plant species) and land management. No significant differences were observed in the dry season, which indicates a turnover of the community and that the effects of vegetation cover have been overcome by the water stress (Table 2). Comparing all experimental plots, total PLFA content correlated significantly with soil water content $(\mathrm{r}=0.403, \mathrm{p} \leq 0.01)$.

The shifts in the microbial community structure due to vegetation cover and seasonal patterns were mostly indicated by differences in the abundance of the same specific groups, as there was no exclusion or unique presence of a particular group of microorganisms in the analyzed PLFA profiles.

Principal component analyses (PCA) of PLFA profiles showed that the first three principal components explained $60.5 \%$ of data variability. Both the first and third principal components contributed to the separation of the pasture site from the native plots ("Cerrado ss" and "campo sujo"), explaining 34.9\% and $10.9 \%$ of the total PLFA variability, respectively (Figure $2 \mathrm{~A}$ ). Some lipids could be used as indicators of shifts in soil microbial community of Cerrado soils,

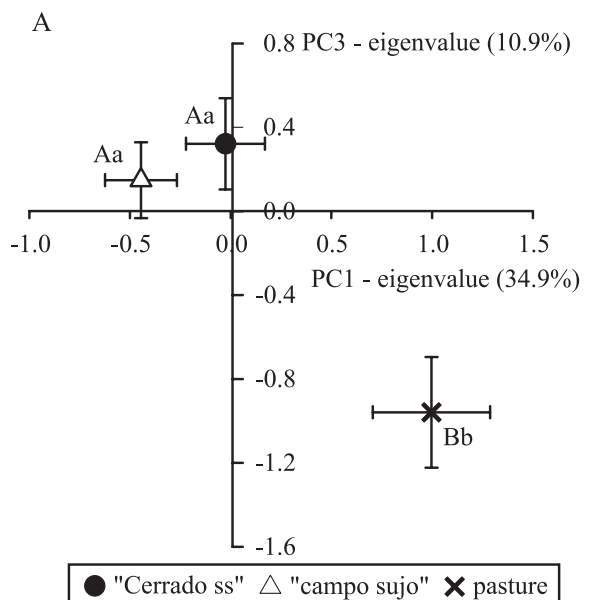

"Cerrado ss" $\triangle$ "campo sujo" $\mathbf{X}$ pasture
B

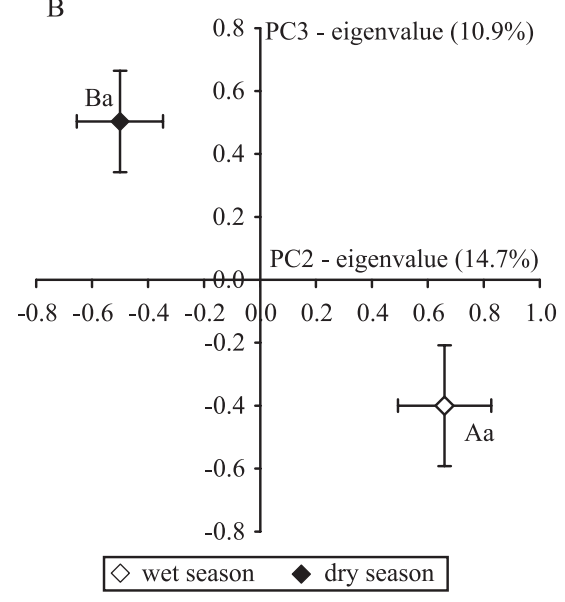

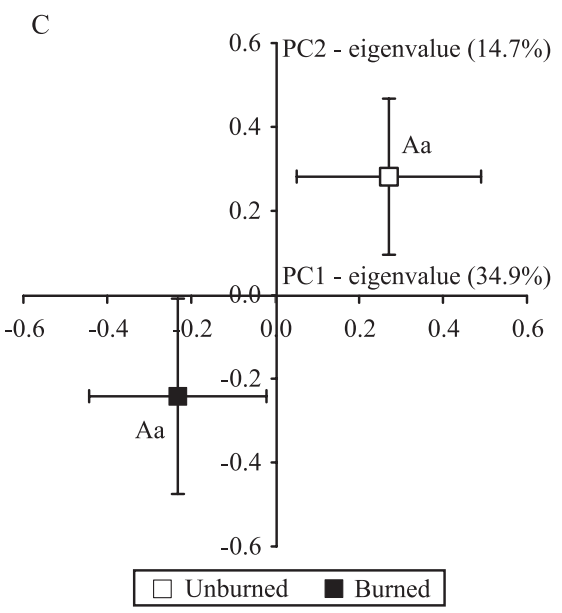

Figure 2. Distribution of principal component scores as a function of vegetation cover (A), seasonality (B) and burning treatment $(\mathrm{C})$. Means \pm standard error followed by equal letters, capital comparing means at $\mathrm{X}$ axis and lower case at $\mathrm{Y}$ axis, do not differ by Tukey test, at $5 \%$ probability. 
due to changes in their concentration in response to site and vegetation differences. Gram-negative bacteria were relatively more important in the pasture soils, as indicated by significantly higher concentrations of the monounsaturated fatty acids $-16: 1 \omega 5$ (both seasons) and $16: 1 \omega 7 \mathrm{c}$ (dry season only) (O'Leary \& Wilkinson, 1988; Federle, 1986). In the wet season, the native plots tended to have higher concentrations of the saturated fatty acids - br19:0 and br20:0 -, which are indicative of Gram-positive bacteria and eukaryotic organisms (Federle, 1986; O’Leary \& Wilkinson, 1988).

Previous studies suggest that soils with high alkalinity (Baath et al., 1995), fertility status (Yao et al., 2000), lower soil moisture (Drenovsky et al., 2010) and pasture land cover (Zelles, 1999) favor the establishment of Gram-negative bacteria. Furthermore, some Gram-negative bacteria, such as Azospirillum, are nitrogen fixers associated with grass roots (like Urochloa) which can be contributing to the amount of Gram-negative biomarkers present in pasture sites (Reis et al., 2001).

Soil microbial community structure also showed a distinct seasonal pattern (dry $\mathrm{x}$ wet season) as indicated by PC2, which had a positive score during the wet season, while it was negative during the dry season (Figure 2 B). The PLFAs 15:0, i16:0 and br18:0 contributed positive loadings to $\mathrm{PC} 2$ and tended to be in higher concentrations during the wet season (Table 3). The lipid i16:0 had a significantly higher mole fraction in both the "Cerrado ss" and pasture sites during the wet season, whereas br18:0 was only significantly higher in the "Cerrado ss". The most common PLFAs extracted during the dry season were

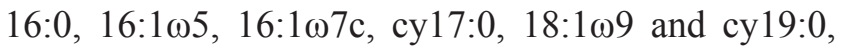
which contributed negative loadings to PC2. Although these lipids had a tendency to be more abundant during the dry season (a period of more stress to the cells due to high temperature and lack of moisture), only $16: 1 \omega 5$ had a significantly higher concentration in the pasture site for the "Cerrado ss". Higher concentration of cy 19:0 in the pasture site, during the dry period, can be explained by the fact that bacteria containing this fatty acid are able to maintain a more stable cell membrane by minimizing changes in membrane fluidity due to cellular degradation under environmental stress (Guckert et al., 1986). PC2 and PC3 together explained $25.6 \%$ of the total PLFA variability. Moore-Kucera \& Dick (2008) observed the effect of clear-cutting and stand age on temporal dynamics of soil microbial community, and noticed that, although PLFA patterns shifted because the effect of clear-cutting, seasonal changes were more significant than differences among stand ages, probably due to variations of availability of nutrients and water throughout the year. Although the experimental design of the present study did not include pasture without grazing, it is noteworthy that grazing might also affect soil microbial community as showed by Clegg (2006) for grasslands in England. The analysis of PLFA in that study indicated a significant interaction between grazing and $\mathrm{N}$ fertilization on the abundance of individual PLFAs.

Principal component analysis of only the native plots indicated no effect of burning on the soil microbial community structure (Figure $2 \mathrm{C}$ ). This result suggests a resilience of the microbial community to the applied fire regime (burning every two years at the end of the dry season). Soon after burning, the onset of the wet season produces a strong change in the microbial community, which might be masking potential effects produced by the fire treatment. Changes in the litter quality, higher

Table 3. Phospholipid fatty acid (PLFA) (mol\%) which best describe seasonality in principal component analysis (PC2) in unburned native plots ("Cerrado ss" and "campo sujo") and pasture plot $^{(1)}$.

\begin{tabular}{|c|c|c|c|c|}
\hline PLFA & Season & "Cerrado ss" & "Campo sujo" & Pasture \\
\hline \multirow{2}{*}{$15: 00$} & dry & $0.56 \pm 0.39 \mathrm{Aa}$ & $0.72 \pm 0.33 \mathrm{Aa}$ & $0.72 \pm 0.31 \mathrm{Aa}$ \\
\hline & wet & $1.05 \pm 0.52 \mathrm{Aa}$ & $0.90 \pm 0.48 \mathrm{Aa}$ & $0.97 \pm 0.28 \mathrm{Aa}$ \\
\hline \multirow{2}{*}{ i16:0 } & dry & $4.16 \pm 2.06 \mathrm{Ab}$ & $4.31 \pm 1.92 \mathrm{Aa}$ & $4.59 \pm 0.68 \mathrm{Ab}$ \\
\hline & wet & $6.89 \pm 0.84 \mathrm{Aa}$ & $5.86 \pm 1.46 \mathrm{Aa}$ & $5.66 \pm 0.57 \mathrm{Aa}$ \\
\hline \multirow{2}{*}{$16: 1 \omega 5$} & dry & $1.61 \pm 0.78 \mathrm{Ba}$ & $1.82 \pm 0.85 \mathrm{Ba}$ & $4.22 \pm 1.80 \mathrm{Aa}$ \\
\hline & wet & $1.66 \pm 0.36 \mathrm{Ba}$ & $1.60 \pm 0.34 \mathrm{Ba}$ & $2.45 \pm 0.38 \mathrm{Ab}$ \\
\hline \multirow{2}{*}{$16: 1 \omega 7 \mathrm{c}$} & dry & $0.98 \pm 0.69 \mathrm{Ba}$ & $1.44 \pm 0.67 \mathrm{Ba}$ & $2.27 \pm 0.29 \mathrm{Aa}$ \\
\hline & wet & $1.15 \pm 0.62 \mathrm{Ba}$ & $1.40 \pm 0.28 \mathrm{ABa}$ & $2.10 \pm 0.48 \mathrm{Aa}$ \\
\hline \multirow{2}{*}{ i17:00 } & dry & $3.95 \pm 1.91 \mathrm{Aa}$ & $4.01 \pm 1.81 \mathrm{Aa}$ & $3.62 \pm 0.31 \mathrm{Aa}$ \\
\hline & wet & $5.40 \pm 1.01 \mathrm{Aa}$ & $5.53 \pm 0.89 \mathrm{Aa}$ & $5.15 \pm 1.85 \mathrm{Aa}$ \\
\hline \multirow{2}{*}{ cy 17:0 } & dry & $0.77 \pm 0.53 \mathrm{Aa}$ & $0.70 \pm 0.49 \mathrm{Aa}$ & $1.31 \pm 0.28 \mathrm{Aa}$ \\
\hline & wet & $0.76 \pm 0.40 \mathrm{Aa}$ & $0.75 \pm 0.39 \mathrm{Aa}$ & $0.97 \pm 0.51 \mathrm{Aa}$ \\
\hline \multirow{2}{*}{ br18:0 } & dry & $2.61 \pm 1.21 \mathrm{Ab}$ & $2.39 \pm 1.06 \mathrm{Aa}$ & $1.72 \pm 0.16 \mathrm{Aa}$ \\
\hline & wet & $3.51 \pm 0.67 \mathrm{Aa}$ & $2.73 \pm 1.41 \mathrm{ABa}$ & $1.76 \pm 0.90 \mathrm{Ba}$ \\
\hline \multirow{2}{*}{$18: 1 \omega 7 \mathrm{c}$} & dry & $4.36 \pm 2.06 \mathrm{Aa}$ & $3.98 \pm 1.79 \mathrm{Aa}$ & $5.30 \pm 0.41 \mathrm{Aa}$ \\
\hline & wet & $5.90 \pm 1.19 \mathrm{Aa}$ & $4.45 \pm 1.06 \mathrm{Aa}$ & $5.15 \pm 0.99 \mathrm{Aa}$ \\
\hline \multirow{2}{*}{ br19:00 } & dry & $3.62 \pm 2.01 \mathrm{Aa}$ & $4.96 \pm 2.37 \mathrm{Aa}$ & $3.13 \pm 0.68 \mathrm{Ab}$ \\
\hline & wet & $5.12 \pm 1.31 \mathrm{ABa}$ & $7.29 \pm 1.95 \mathrm{Aa}$ & $4.60 \pm 1.13 \mathrm{Ba}$ \\
\hline \multirow{2}{*}{ cy19:00 } & dry & $12.10 \pm 5.58 \mathrm{Aa}$ & $12.27 \pm 6.07 \mathrm{Aa}$ & $10.09 \pm 1.50 \mathrm{Aa}$ \\
\hline & wet & $13.58 \pm 3.06 \mathrm{Aa}$ & $12.66 \pm 1.84 \mathrm{ABa}$ & $9.59 \pm 2.40 \mathrm{Ba}$ \\
\hline \multirow{2}{*}{ br20:00 } & dry & $0.79 \pm 0.60 \mathrm{Aa}$ & $1.08 \pm 0.82 \mathrm{Ab}$ & $1.03 \pm 0.15 \mathrm{Aa}$ \\
\hline & wet & $1.44 \pm 0.45 \mathrm{ABa}$ & $2.11 \pm 0.57 \mathrm{Aa}$ & $1.07 \pm 0.67 \mathrm{Ba}$ \\
\hline
\end{tabular}

${ }^{(1)}$ Means \pm standard deviation followed by equal letters, capital in lines and lower case in columns by season, do not differ by Tukey test, at $5 \%$ probability. 
soil $\mathrm{pH}$ and modifications in the soil structure caused by fire, could be important factors determining what kind of microorganisms will colonize the area (Pietikainen et al., 2000). Prescribed fires in cerrado plots resulted in reduction of soil inorganic nitrogen concentration and mineralization rates (Nardoto \& Bustamante, 2003), decreases in woody species density (Moreira, 2000) and litter input (Nardoto et al., 2006) for the unburned sites. Despite these responses, the PLFA profiles from the microbial community did not show a similar level of response to fire, which might suggest that the belowground conditions are not shifting as rapidly as the controlling aboveground conditions. The significant shift in structure, produced when native savanna vegetation is converted to pasture, indicates that land use changes produce a stronger response in soil microbiota.

\section{Conclusions}

1. Land cover and seasonal rainfall distribution in Cerrado ecosystems affect total density of soil microorganisms at $0-5 \mathrm{~cm}$ layer depth, expressed as mean of total phospholipid fatty acid abundance, and the abundance of microbial groups, especially Gram-negative and Gram-positive bacteria.

2. Burning woody covers of cerrado stricto sensu and campo sujo vegetation, at the end of dry season, do not affect the structure of soil microbial community at $0-5 \mathrm{~cm}$ layer depth.

\section{Acknowledgements}

To the staff of Reserva Ecologica of Instituto Brasileiro de Geografia e Estatística, the Embrapa Cerrados and the United States Environmental Protection Agency (USEPA) (Athens, GA); to Lourival Vilela, Alexandre Barcellos, Éder Martins, Ieda Mendes, Renato Varella, Karinne Pereira, Joana Dias Bresolin, Catarina Garofalo and Maria Regina Sartori Silva, for their help during this study; to the National Aeronautics and Space Administration under Large-Scale Biosphere-Atmosphere project ND-07 and to USEPA through the Assistance Agreement 827291-01. Although this work was reviewed by the USEPA and approved for publication, it might notnecessarily reflect Agency policy. Mention of trade names or commercial products does not constitute endorsement or recommendation for use.

\section{References}

BAATH, E.; ANDERSON, T.-H. Comparison of soil fungal/ bacterial ratio in a $\mathrm{pH}$ gradient using physiological and PLFA-based techniques. Soil Biology and Biochemistry, v.35, p.955-963, 2003.

BAATH, E.; FROSTEGARD, A.; PENNANEN, T.; FRITZE, H. Microbial community structure and $\mathrm{pH}$ response in relation to soil organic matter quality in wood-ash fertilized, clear-cut or burned coniferous forest soils. Soil Biology and Biochemistry, v.27, p.229-240, 1995.

BLIGH, E.G.; DYER, W.J. A rapid method of total lipid extraction and purification. Canadian Journal of Biochemistry and Physiology, v.37, p.911-917, 1959.

BORGES, F.J.A.; MARINI, M.A. Birds nesting survival in disturbed and protected neotropical savannas. Biodiversity and Conservation, v.19, p.223-236, 2010.

BOSSIO, D.A.; SCOW, K.M.; GUNAPALA, N.; GRAHAM, K.J. Determinants of soil microbial communities: effects of agricultural management, season, and soil type on phospholipid fatty acid profiles. Microbial Ecology, v.36, p.1-12, 1998.

CLEGG, C.D. Impact of cattle and inorganic fertilizer additions to managed grassland on the microbial community composition of soils. Applied Soil Ecology, v.31, p.73-82, 2006.

DRENOVSKY, R.E.; STEENWERTH, K.L.; JACKSON, L.E.; SCOW, K.M. Land use and climatic factors structure regional patterns in soil microbial communities. Global Ecology and Biogeography, v.19, p.27-39, 2010.

DURIGAN, G.; SIQUEIRA, M.F. de; FRANCO, G.A.D.C. Threats to the Cerrado remnants of the state of São Paulo, Brazil. Scientia Agricola, v.64, p.355-363, 2007.

EISENHAUER, N.; BESSLER, H.; ENGELS, C.; GLEIXNER, G.; HABEKOST, M.; MILCU, A.; PARTSCH, S.; SABAIS, A.C.W.; SCHERBER, C.; STEINBEISS, S.; WEIGELT, A.; WEISSER, W.W.; SCHEU, S. Plant diversity effects on soil microorganisms support the singular hypothesis. Ecology, v.91, p.485-496, 2010.

FEDERLE, T.W. Microbial distribution in soil - new techniques. In: MEGUSAR, F.; GANTAR, M. (Ed.). Perspectives in microbial ecology. Ljubljana: Slovene Society for Microbiology, 1986. p.493-498.

GUCKERT, J.B.; HOOD, M.A.; WHITE, D.C. Phospholipids ester-linked fatty acid profile changes during nutrient deprivation of Vibrio cholerae: increases in the trans/cis ratio and proportions of cyclopropyl fatty acids. Applied and Environmental Microbiology, v.52, p.794-801, 1986.

HABEKOST, M.; EISENHAUER, N.; SCHEU, S.; STEINBEISS, S.; WEIGELT, A.; GLEIXNER, G. Seasonal changes in the soil microbial community in a grassland plant diversity gradient four years after establishment. Soil Biology and Biochemistry, v.40, p.2588-2595, 2008.

HEIPIEPER, H.J.; MEULENBELD, G.; OIRSCHOT, Q. van; BONT, J.A.M. de. Effect of environmental factors on the trans/ cis ratio of unsaturated fatty acids in Pseudomonas putida S12. Applied and Environmental Microbiology, v.62, p.2773-2777, 1996.

Pesq. agropec. bras., Brasília, v.46, n.12, p.1665-1672, dez. 2011 
KATO, E. Efeito da queimada na estabilidade de agregados, na resistência ao selamento superficial e na taxa de infiltração de água em solos de Cerrado. 2001. 58p. Tese (Doutorado) Universidade de Brasília, Brasília.

MIRANDA, H.S.; BUSTAMANTE, M.M.C.; MIRANDA, A.C. The fire factor. In: OLIVEIRA, P.S.; MARQUIS, R.J. (Ed.). The Cerrados of Brazil: ecology and natural history of a neotropical savanna. New York: Columbia University, 2002. p.51-68.

MITTERMEIER, R.A.; GIL, P.R.; HOFFMANN, M.; PILGRIM, J.; BROOKS, T.; MITTERMEIER, C.G.; LAMOREUX, J.; FONSECA, G.A.B. da. Hotspots revisited: earth's biologically richest and most endangered terrestrial ecoregions. Washington: Conservation International, 2005. 392p.

MOORE-KUCERA, J.; DICK, R.P. PLFA profiling of microbial community structure and seasonal shifts in soils of a Douglas-fir chronosequence. Microbial Ecology, v.55, p.500-511, 2008.

MOREIRA, A.G. Effects of fire protection on savanna structure in Central Brazil. Journal of Biogeography, v.27, p.1021-1029, 2000 .

NARDOTO, G.B.; BUSTAMANTE, M.M. da C. Effects of fire on soil nitrogen dynamics and microbial biomass in savannas of Central Brazil. Pesquisa Agropecuária Brasileira, v.38, p.955-962, 2003.

NARDOTO, G.B.; BUSTAMANTE, M.M. da C.; PINTO, A.S.; KLINK, C.A. Nutrient use efficiency at ecosystem and species level in savanna areas of Central Brazil and impacts of fire. Journal of Tropical Ecology, v.22, p.191-201, 2006.

O'LEARY, W.M.; WILKINSON, S.G. Gram-positive bacteria. In: RATLEDGE, C.; WILKINSON, S.G. (Ed.). Microbial lipids. London: Academic, 1988. p.117-185.

PERSSON, T.; LUNDKVIST, H.; WIRÉN, A.; HYVÖNEN, R.; WESSÉN, B. Effects of acidification and liming on carbon nitrogen mineralization and soil microorganisms in mor humus. Water, Air, and Soil Pollution, v.45, p.77-96, 1989.

PIETIKAINEN, J.; HIUKKA, R.; FRITZE, H. Does short-term heating of forest humus change its properties as a substrate for microbes? Soil Biology and Biochemistry, v.32, p.277-288, 2000 .

REIS, V.M.; REIS, F.B.; QUESADA, D.M.; OLIVEIRA, O.C.A.; ALVES, B.J.R.; URQUIAGA, S., BODDEY, R.M. Biological nitrogen fixation associated with tropical pasture grasses.
Australian Journal of Plant Physiology, v.28, p.837-844, 2001.

SANO, E.E.; ROSA, R.; BRITO, J.L.S.; FERREIRA, L.G. Mapeamento semidetalhado do uso da terra do bioma Cerrado. Pesquisa Agropecuária Brasileira, v.43, p.153-156, 2008.

SANTOS, H.G. dos; JACOMINE, P.K.T.; ANJOS, L.H.C. dos; OLIVEIRA, V.A. de; OLIVEIRA, J.B. de; COELHO, M.R.; LUMBRERAS, J.F.; CUNHA, T.J.F. (Ed.). Sistema brasileiro de classificação de solos. 2.ed. Rio de Janeiro: Embrapa Solos, 2006. $306 \mathrm{p}$.

SWALLOW, M.; QUIDEAU, S.A.; MACKENZIE, M.D.; KISHCHUK, B.E. Microbial community structure and function: the effect of silvicultural burning and topographic variability in northern Alberta. Soil Biology and Biochemistry, v.41, p.770-777, 2009.

TUNLID, A.; WHITE, D.C. Biochemical analysis of biomass, community structure, nutritional status and metabolic activity of microbial community in soil. In: STOTZKY, C.; BOLLAG, J.-M. (Ed.). Soil biochemistry. New York: Marcel Dekker, 1992. v.7, p.229-262.

VARELLA, R.F.; BUSTAMANTE, M.M.C.; PINTO A.S.; KISSELLE, K.W.; SANTOS, R.V.; BURKE, R.A.; ZEPP, R.G.; VIANA, L.T. Soil fluxes of $\mathrm{CO}_{2}, \mathrm{CO}, \mathrm{NO}$ and $\mathrm{N}_{2} \mathrm{O}$ from an old pasture and from native savanna in Brazil. Ecological Applications, v.14, p.221-231, 2004. Supplement.

WHITE, D.C.; DAVIS, W.M.; NICKELS, J.S.; KING, J.D.; BOBBIE, R.J. Determination of the sedimentary microbial biomass by extractable lipid phosphate. Oecologia, v.40, p.51-62, 1979.

WILKINSON, S.G. Gram-negative bacteria. In: RATLEDGE, C.; WILKINSON, S.G. (Ed.). Microbial lipids. London: Academic, 1988. p.299-488.

YAO, H.; HE, Z.; WILSON, M.J.; CAMPBELL, C.D. Microbial biomass and community structure in a sequence of soils with increasing fertility and changing land use. Microbial Ecology, v.40, p.223-237, 2000

ZELLES, L. Fatty acid patterns of phospholipids and lipopolysaccharides in the characterization of microbial communities in soil: a review. Biology and Fertility of Soils, v.29, p.111-129, 1999.

ZELLES, L.; BAI, Q.Y. Fractionation of fatty acids derived from soil lipids by solid phase extraction and their quantitative analysis by GC-MS. Soil Biology and Biochemistry, v.25, p.495-507, 1994.

Received on February 17, 2011 and accepted on August 15, 2011 